\title{
The Role of Teachers in The Curriculum of Local Contents in SD Negeri 176 OKU Kandang Macan Sinar Peninjauan Sub-District
}

\author{
Nazarudin Latif ${ }^{1 *}$, Destiniar ${ }^{2}$, Syarwani Ahmad ${ }^{2}$ \\ ${ }^{1}$ PKBM AL-GHOZALI Lubuk Banjar OKU, Indonesia \\ ${ }^{2}$ Universitas PGRI Palembang, Indonesia \\ *Corresponding author. Email: 01nazarudinlatif@gmail.com
}

\begin{abstract}
The goal of this study was to determine the role of teachers in developing the local content curriculum at SD Negeri 176 OKU Kandang Macan Sinar Peninjauan. This review uses qualitative approaches with a descriptive research style. Local material teachers at SD Negeri 176 OKU Kandang Macan were the informants of this report. Research data were analyzed through data reduction, data presentation and conclusions drawn. Results have shown that: (1) the role of a teacher as an educator is to fully understand students, help students find character, build good character and promote bad characters in the learning process of local content; (2) The role of the teacher as a teacher is a technical role, where the teacher as a teacher focuses on the experience, skills and abilities of the students' local content; (3) the role of the teacher as a guide is to guide all aspects of education, both academic and non-academic.
\end{abstract}

Keywords: The Role of Teachers, Development, Local Content

\section{INTRODUCTION}

Education is the most significant predictor for the growth of a nation [1]. Mantriri [2] points out that education is one factor that affects the development of the nation in order to enhance the quality of human capital. This is because education plays a key role in the training of human capital [3]. Curriculum is one of the primary elements of schooling. Curriculum is one of the methods for achieving educational objectives, as well as a guide for the application of learning at all levels and at all levels of education [4]. Nisa [5] said that the curriculum must always be improved. Curriculum creation is carried out as an anticipatory phase in reacting to the problems that occur as a result of these changes, while at the same time paying attention to the situation and circumstances as well as the norms that apply to society [6]. Curriculum production is divided into national curriculum and local curriculum.

The Local Curriculum is a curriculum that is structured in areas known as the Local Content Curriculum, and is an instructional program in the form of subjects containing local knowledge-based materials or learning materials, relating to content standards, method standards and evaluation standards. Set up by the local government [7]. One of the primary schools in
Ogan Komering Ulu district, SDN 176 OKU Kandang Macan, Sinar Peninyau District, has introduced a local learning program. Of course, the task of teacher in the school is to introduce the local content curriculum at SDN 176 OKU Kandang Macan, Sinar Peninjauan District. Dhani [4] states that one of the figures that plays such an important role in the development of curriculum in educational institutions is the teacher.

The role of teachers in the development of curriculum is very influential in the learning process, which will be both central and decentralized, since both involve the development of a teacher's role [5]. Teachers, as central players in education, are expected to fulfill their responsibilities as competent educators and, of course, as curriculum writers [4]. In this case, the teacher has an important role to play in the creation of a decentralized curriculum, namely the role of the teacher in the development of curriculum compiled by some schools or school groups in the area or country [8]. Teachers have three important roles to play in creating a local content curriculum, namely a teacher as an instructor, a teacher as a teacher, and a teacher as a guide. Qualified teachers can also produce quality students [9]. Teachers as a leading sector in educating students, it is necessary for the guidance of the principal 
in order to improve the work ethic of teachers to carry out learning activities [10].

Ihsan [11] describes educators as adults who are responsible for providing guidance and assistance to students in their physical and spiritual growth in order to achieve maturity, capable of fulfilling their duties as creatures of Allah SWT, caliphs on the surface of the earth, social beings and individuals capable of standing on their own. Mulyasa [12] states that teachers are equivalent to travel guides, who are responsible for a smooth trip on the basis of their expertise and experience. The word "travel" refers not only to the physical, but also to the mental, emotional, artistic, moral and spiritual journey that is deeper and more nuanced.

\section{METHODS}

This study uses a qualitative approach with a descriptive style of research. Primary data were taken from local content teachers at SD Negeri 176 OKU Kandang Macan Sinar Peninjauan as informants, while secondary data were in the form of documents, activity images, archives, and other data that supported primary data. The methods for gathering data in this study were interviews, observation and recording. Data analysis methods in this study included data reduction, data presentation and conclusion drawing. Data to verify the used triangulation, namely technological triangulation and time triangulation.

\section{RESULTS AND DISCUSSION}

\section{A. SD Negeri 176 Local Content Curriculum OKU Kandang Macan Sinar Peninjauan}

Results have shown that SD Negeri 176 OKU Kandang Macan Sinar Peninjauan local content curriculum is an environmentally focused agricultural local content curriculum. Arifin [13] notes that local content is a type of curriculum that is organized according to the variety and potential that exists in their respective environments, as outlined in a set of plans and arrangements for content and materials prepared by educational units for the implementation of learning activities aimed at the achievement of certain education.

It can be concluded that the environmental-oriented agricultural local content curriculum implemented by SD Negeri 176 OKU Kandang Macan Sinar Peninjauan is a type of curriculum based on the means of using the potential environment in the school in writing, which is part of a set of plans and compiled by the Education Unit for the implementation of learning activities.

\section{B. The role of teachers as educators in developing the local content curriculum at SD Negeri 176 OKU Kandang Macan Sinar Peninjauan}

The findings showed that: (a) the teacher was able to completely understand the students because the students were unable to find their personality without the help of adults, in this case the teacher; (b) the teacher helped the students to find the character of the students so that the students could become a better person while they are in the school setting and outside the school; and (c) the teacher.

This is in line with Zahro [14] who notes that teachers must be obliged to find characters possessed by students, that they must also strive to motivate students to grow good characters and encourage bad characters so that they do not develop, and that they must be able to provide feedback in the form of encouragement when students have trouble developing their potential. Syarifudin [15] also said that the role of teachers as educators is to humanize people, students are human beings who have not become completely human, so the role of adults is required to educate them. Teachers must use it interchangeably with teachers of other grade levels [16].

It can be concluded that the role of teachers as educators in creating a local content curriculum at SD Negeri 176 OKU Kandang Macan Sinar Peninjauan is that teachers can carry out their duties as educators, i.e. fully understanding students, helping students find character, developing good characters and promoting bad characters. In the process of learning material locally. So, through the position of teacher, the local content curriculum, students at SD Negeri 176 OKU Kandang Macan Sinar Peninjauan can become completely human. To ensure that the creation of a local content curriculum can be carried out in the role of a teacher as an educator.

\section{The role of a teacher in developing a local content curriculum at SD Negeri 176 OKU Kandang Macan Sinar Peninjauan}

The findings showed that teachers of local content concentrated on mastery of knowledge, skills and expertise. This is in line with Nurhaidah and Insya [17] who state that with their teachers, Indonesian people will have knowledge, skills and expertise. In line with Uno [18], which notes that teachers must be able to draw the attention of students to the material presented, teachers must also be able to stimulate the interest of students to be interested in thought and to search and find their own information.

It can be assumed that the role of the teacher as a teacher in designing the local content curriculum at SD Negeri 176 OKU Kandang Macan Sinar Peninjauan is a technical role, where the teacher as a teacher focuses on the awareness, skills and expertise of students. The 
information, skills and expertise of students are gained directly or indirectly from the teacher, that is to say, the teacher awakens students so that they can think about discovering and finding their own problems. So, through the role of the teacher, local content curriculum students at SD Negeri 176 OKU Kandang Macan Sinar Peninjauan can have knowledge, skills and expertise. To ensure that the creation of a local content curriculum can be carried out through the role of the teacher as a teacher.

D. The role of the teacher as a guide to the creation of the local content curriculum at SD Negeri 176 OKU Kandang Macan Sinar Peninjauan

The findings have shown that the teacher has given instruction to students in both academic and nonacademic fields. This is consistent with Mulyasa [12], which notes that teachers are equivalent to travel guides. The term journey concerns not only physical, but also mental, emotional, artistic, moral and even spiritual journeys that are deeper and more nuanced. Rijal [19] also notes that the guidance offered by teachers is not only related to awareness, but also to the personality and the development of student values. Teachers such as teachers are a profession whose job is to carry out education in an elementary and high school by using various learning methods to meet their learning targets [20].

It can be concluded that the role of the teacher as a guide in the creation of the local content curriculum at SD Negeri 176 OKU Kandang Macan Sinar Peninjauan is to guide all aspects of education, both academic and non-academic. Thus, through the role of the teacher, the local content curriculum, students at SD Negeri 176 OKU Kandang Macan Sinar Peninjauan will grow and evolve to be better and more focused, both on the aspects of knowledge, pregnancy and knowledge, as well as on the character of students. In order to create a local content curriculum, the role of the teacher as a guide can be carried out.

\section{CONCLUSION}

Based on the results of the study, the researcher may infer a variety of things as follows: 1) SD Negeri 176 OKU Kandang Macan Sinar Pengininan Curriculum for Local Content is an environmental agriculture curriculum with local content; 2) teachers' job as educators is to fully understand students, help students find character and create good characters and encourage bad characters in the learning process of local content; 3 ) the role of the teacher as a teacher is a technical role in which the teacher as a teacher relies on the experience, skills and expertise of the learners' local content, and 4) the task of the teacher as a guide is to guide all aspects of education, both academic and nonacademic.

\section{ACKNOWLEDGMENTS}

The author would like to thank Dr. H. Bukman Lian, M.M., M.Si., Chancellor of the PGRI Palembang University, Dr. Syaiful Eddy, M.Sc., Director of the Postgraduate Program at the PGRI Palembang University, Dr. Happy Fitria, M.Pd., Head of Education Management Study Program and all those who have helped morally and materially. May the goodness become multiple good deed.

\section{REFERENCES}

[1] Asvio, N., Yamin, M., \& Risnita. (2019). Influence of Leadership Style, Emotional Intelligence and Job Satisfaction toward Organizational Commitment (Survey at SMA Muhammadiyah South Sumatera). International Journal of Scientific \& Technology Research 8 (8).

[2] Mantiri, J. (2019). Peran Pendidikan dalam Menciptakan Sumber Daya Manusia Berkualitas di Provinsi Sulawesi Utara [The Role of Education in Creating Quality Human Resources in North Sulawesi Province]. Jurnal Civio Education. Volumen 3, hal. 20-26.

[3] Abidin, A. A. (2017). Manajemen Pembiayaan Pendidikan Tinggi dalam Upaya Peningkatan Mutu (Studi Kasus pada Perguruan Tinggi Swasta Menengah di Surabaya) [Management of Higher Education Financing in Quality Improvement Efforts (Case Study at Private Middle Universities in Surabaya)]. Jurnal Manajemen Pendidikan. Volume 2, hal. 168-177.

[4] Dhani, R. R. (2020). Peran Guru dalam Mengambangkan Kurikulum [The Role of Teachers in Developing Curriculum]. Jurnal Serunai Administrasi Pendidikan. Volume 9 (hlm. 45-50).

[5] Nisa, K. (2018). Peran Guru dalam Pengembangan Kurikulum Pendidikan Islam [The Role of Teachers in Islamic Education Curriculum Development]. Jurnal Inovatif. Volume 4 (hlm. 4456).

[6] Zamili, U. (2020). Peranan Guru dalam Pengembangan Kurikulum [Curriculum Development Theory and Practice]. Jurnal Pionir LPPM Universitas Asahan. Volume 6 (hlm. 311318).

[7] Idi, A. (2016). Pengembangan Kurikulum Teori dan Praktek [Development of Theory and Practice Curriculum]. Jogjakarta: Ar-ruuz Media.

[8] Sukmadinata. (2013). Pengembangan Kurikulum Teori dan Praktek [Development of Curriculum 
Theory and Practice]. Bandung: PT. Remaja Rosdakarya.

[9] Hanim, H., \& Rahmadoni, J. (2020). Determination of Lecturer Reception Using Analytical Hierarchy Process (AHP). Journal of Applied Engineering and Technological Science (JAETS), 1 (2), 136141.

[10] Murtiningsih, Kristiawan, M., \& Lian, B. (2019). The Correlation Between Supervision of Headmaster and Interpersonal Communication with Work Ethos of The Teacher. European Jurnal of Education Studies 6(1). Retrieved from http://dx.doi.org/10.46827/ejes.v0i0.2398

[11] Ihsan, H. (2001). Filsafat Pendidikan Islam [Philosophy of Islamic Education]. Bandung: Pustaka Setia.

[12] Mulyasa. (2011). Manajemen dan Kepemimpinan Kepala Sekolah [Principal Management and Leadership]. Jakarta: PT. Bumi Aksara.

[13] Arifin, Z. (2011). Konsep dan Model Pengembangan Kurikulum [Concept and Model of Curriculum Development]. Bandung: PT. Remaja Rosdakarya.

[14] Zahro, A. (2015). Membangun Kualitas Pembelajaran melalui Dimensi Profesional Guru [Building Quality of Learning through Teacher Professional Dimensions]. Bandung: Yrama Widya.

[15] Syarifuddin. (2015). Guru Profesional: Dalam Tugas Pokok dan Fungsi (Tupoksi) [Professional Teachers: In Main Duties and Functions (Tupoksi)]. Volume 3 (hlm. 65-84).

[16] Primasari, D. A. G., Kristiawan, M., \& Fitria, H. (2020). Developing Instructional Media of Curriculum 2013 Based on Information and Communication Technology. Education Journal 3(2), 24-34. http://www.itspoa.com/?thread-1089111.html

[17] Nurhaidah, M., \& Insya, M. (2016). Pengembangan Kompetensi Guru terhadap Pelaksanaan Tugas dalam Mewujudkan Tenaga Guru yang Profesional [Development of Teacher Competence in Implementation of Tasks in Realizing Professional Teachers]. Jurnal Pesona Dasar. Volume 2 (hlm. 8-27).

[18] Uno, H.B. (2007). Profesi Kependidikan: Problem, Solusi, dan Reformasi Pendidikan di Indonesia [Education Profession: Problems, Solutions, and Educational Reform in Indonesia]. Jakarta: Bumi Aksara.
[19] Rijal. (2016). Guru sebagai Pembimbing dan Pengajar [Teachers as Guides and Lecturers]. Diakses https://rijal09.com/2016/03/vbehaviorurldefaultvmlo_10.html tanggal $20 \mathrm{Juli}$ 2020 pada pukul $10.00 \mathrm{Wib}$

[20] Rahmadoni, J., Arifnur, A. A., \& Wahyuni, U. M. (2020). Penerapan Schoology Sebagai Learning Management System Bagi Guru SMAN 1 Sutera [Implementation of Schoology as a Learning Management System for Teachers of SMAN 1 Sutera]. Jurnal Hilirisasi IPTEKS volume 3 No 2. 